\title{
1. Analysing the prosperity gap: the economic, legal, and political challenges facing the EU
}

\section{Ulf Bernitz, Moa Mårtensson, Lars Oxelheim, and Thomas Persson}

\section{INTRODUCTION}

The European Union (EU) is currently experiencing its greatest existential crisis since it came into being in the aftermath of World War II. The origins of the current challenges are to be found in three intertwined developments.

First, the global financial and economic crisis - often referred to as the Great Recession - posed a serious threat to the common currency, and it has rapidly widened the gap between rich and poor citizens in many European countries (Keeley 2015; EU SPC 2016). Moreover, the austerity policies prescribed for the countries most affected by the crisis - primarily in the Balkans and southern Europe - have increased the gap between richer and poorer member states (Raitano 2016). A growing prosperity gap has developed within the EU, giving rise to new doubts that the ideas of 'solidarity' and 'Europe' can be combined (cf. Ferrera 2005).

Second, the global refugee crisis has sparked further political debate over questions of solidarity and shared responsibility within the Union. National responses to the challenge have diverged widely. Sharp disagreements have arisen between the so-called Visegrad countries on the one hand, and the main refugee-receiving countries on the other. The former - Hungary, Poland, the Czech Republic, and Slovakia - oppose the European Commission's scheme to redistribute refugees among the member states. The latter - Germany, Sweden, and such southern member states as Italy and Greece - consider migration to be a shared responsibility (Greenhill 2016).

Last but not least, the unexpected decision of the United Kingdom to leave the EU has highlighted the legitimacy deficit of the latter, by exposing the unwillingness of many citizens to accept EU policies on migration and free movement (Portes 2016; Thielemann and Schade 2016). The 
Brexit decision clearly involved a cultural backlash against values such as cosmopolitanism and multiculturalism (Inglehart and Norris 2016). It also revealed growing centre-periphery tensions in matters relating to European integration and global capitalism. Cities and regions in the United Kingdom that have benefitted the most from immigration and trade voted most strongly in favour of remaining, while peripheral regions, characterized by scepticism towards globalization and migration, voted to leave (Arnorsson and Zoega 2016; Streeck 2016).

In the wake of these three intertwined European and global developments, and in view of the severe splits they have caused both within and among the member states, a collapse of the Union can no longer be ruled out. However, if we merely point out the self-interested behaviour of many of the member states in these various crises, we risk overlooking the rootedness of such behaviour in the basic conditions on which European integration builds. The EU, that is to say, is an asymmetric union (Gustavsson 1998; Scharpf 2002). As the three intertwined crises demonstrate, the Union was not primarily designed to help the member states which are worst off. Nor was its purpose to help the citizens who are in greatest need.

Above all, the three crises lay bare the fundamental imbalance that obtains between the economic and social dimensions of European integration. Within the framework of the nation-state, as Scharpf notes (2002, p.665), economic policy on the one hand and social policy on the other developed historically alongside one another. Conducted as they were at the same level, they could be continuously balanced against each other. But European integration separates the two, creating an asymmetric relationship between (Europeanized) economic policies and (national) systems for social sharing:

[T]he course of European integration from the 1950s onward has created a fundamental asymmetry between policies promoting market efficiencies and those promoting social protection and equality. In the nation-state, both types of policy had been in political competition at the same constitutional level. In the process of European integration, however, the relationship has become asymmetric as economic policies have been progressively Europeanized, while social-protection policies remained at the national level.

Social policy remains essentially a national competence within the EU, as does fiscal policy. This sets strict limits on redistribution and social investment on a larger, European scale. To a degree, in fact, the treaties even prevent the member states from helping each other out. This is most evident in the so-called no-bailout clause, which makes it illegal for EU member states to assume one another's debts (Article 125 of the Treaty on the Functioning of the European Union; Castillo Ortiz 2017). 
Despite this, the EU has gradually developed a social dimension. This involves a set of instruments in the social field such as financial support, European legislation, and mechanisms for coordinating national policies making it possible to speak of a 'Social Europe' (Ferrera 2005, 2014; Martinsen and Vollaard 2014; Fernandes and Rinaldi 2016).

Following the election of Jean-Claude Juncker as its president in 2014, the European Commission has taken further steps in this direction. In a speech to the European Parliament (EP) upon his election, Juncker launched the idea that the EU should aim for a 'social triple-A' rating (European Commission 2014a). This commitment subsequently resulted in a European Pillar of Social Rights (European Commission 2016a, 2017), an inquiry into the EU's so-called social acquis (European Commission 2016b), and a massive investment plan for jobs and inclusive growth (European Commission 2014b). But will these measures suffice to map out a new and socially more sustainable line of development for the EU?

This book addresses the great social challenge the EU currently faces. This is a multifaceted problem, requiring interdisciplinary analysis. What can be done to bridge the prosperity gap in Europe? We have asked innovative researchers in economics, law, and political science to tackle this question and to seek out new solutions within their respective fields of expertise.

Several chapters in the book cover crucial policy challenges: What can be done to tackle youth unemployment? How can national social insurance systems be made to work together within the Union? Can austerity policies be made more balanced and sustainable? Is there a better way to implement European social rights?

Other chapters analyse fundamental mechanisms or developments that limit or condition the evolution of a European social dimension: What are the economic costs and benefits of free movement? What are the factors underlying differing levels of trust in countries and regions within the EU? How do radical-right parties make use of the EP as a political arena? Can the social dialogue between trade unions and employer organizations help solve the EU's problems with legitimacy?

We must stress at the outset that no simple solutions to Europe's current dilemmas appear to be available. Nevertheless, the chapters that follow propose measures that may help gradually restore the balance between market integration and social protection in the EU.

Our purpose in this introduction is to do four things, thereby paving the way for discussions in greater depth. First, in the section that follows, we briefly describe the social dimension and its historical development. Second, we identify the new social challenges the Union faces in the wake of the Great Recession, the ongoing refugee crisis, and the Brexit referendum. 
Third, we propose an analytical point of departure for examining these challenges - an interdisciplinary approach that pinpoints a number of overarching problems and possibilities associated with the social dimension of European integration. Fourth and finally, we introduce each of the book's chapters, and the key policy recommendations provided therein.

\section{THE EU'S SOCIAL AGENDA - A BRIEF HISTORY}

The idea of a social dimension in European integration was present as early as 1957, in the Treaty of Rome. But social progress was not a priority for the European Economic Community (EEC). It was expected simply to result, rather, from the economic prosperity brought about by the creation of the common market. Following World War II, far-reaching structural rationalization had hit the coal and steel industries in Europe very hard. To be sure, a common European market promised to open up economic opportunities and to boost trade among the participating states. At the same time, there was an early realization that the costs and benefits of economic integration could end up being unevenly distributed. Certain groups would risk marginalization as a result of economic restructuring. With this danger in mind, the European Social Fund - the very first Structural Fund - was created. Its mandate was to increase the mobility of workers and to enhance their ability to find work in the common market (Majone 1993, p. 153). Those struck by unemployment would be given the opportunity to retrain, or would be helped to move to parts of Europe where new jobs could be found.

The design of the European Social Fund illustrates the level of ambition that has been present from the start. The primary object of the fund has been to reduce economic and social disparities among the countries and regions of the Union. Some support can certainly be provided to particularly vulnerable persons - young people, immigrants, the long-term unemployed - but the Union's aid is mainly aimed at the weakest European regions. The idea is that, by enhancing competitiveness and expanding employment in disadvantaged regions - rather than by targeting assistance directly on vulnerable individuals - the EU's efforts in this area will serve to enhance social cohesion.

Moreover, the redistribution that takes place through the European Social Fund is vanishingly small compared to that which results from the social expenditures of the member states themselves. The Union's budget comes to about 155 billion euros a year (2016), with each country contributing about 1 per cent of its gross national income (GNI) and about 0.3 per cent of its VAT revenues. Of the total EU budget, the European Social 
Fund accounts for some 8 per cent. A much larger portion of the budget goes to agriculture, rural development, and the environment, as well as to regional support through the other Structural Funds. The budgets of the member states taken together are some 50 times larger than the EU budget, and each country on its own spends much greater sums on social welfare (the average expenditure on social protection relative to gross domestic product, GDP, being about 30 per cent, although the variation is considerable).

The imbalance between market integration and social protection is also apparent in the design of the Economic and Monetary Union (EMU), as set out in the Maastricht Treaty of 1993. The so-called Delors Committee, made up of the governors of the central banks of the member states and chaired by the president of the European Commission, Jacques Delors, was responsible for the original outline of the EMU project (Committee for the Study of Economic and Monetary Union 1989). The fundamental idea behind the EMU was that the participating countries would coordinate their economic policies, but never proceed to the next step: a common fiscal union and redistribution (Gustavsson 2002; Jabko 2006). The responsibility for monetary policy would be transferred to an independent central bank for Europe, while fiscal policies would remain in the hands of the member states themselves. Only a limited degree of redistribution would take place through a regional policy based on the annual membership fees paid by the member countries.

But when, in 2008, the crisis struck Europe after the bankruptcy of Lehman Brothers, the US investment bank, ad hoc solutions to save the countries hit by crisis were instead the order of the day. These involved making citizens in the member states (especially those using the euro) fork out hundreds of billions of euros in emergency loans to the worst-hit countries. Meanwhile, central parts of the welfare system in the crisisstruck countries have been dismantled, with growing inequalities as a consequence. It took the global economic and financial crisis to bring the weaknesses of this construction abruptly to light (Scharpf 2012).

Would another course of development have been possible? In certain periods, ambitions for the social dimension of European integration have been much higher. When Jacques Delors took on the role of president of the European Commission in 1985, an intensive phase in the history of the EU began. The Single European Act entered into force on 1 July 1987. In addition to pointing the way to the realization of a single market for goods, services, capital, and labour, this new treaty introduced certain provisions for a common social policy, above all in connection with questions of health and safety at work. It contained, moreover, a new treaty title: that of Economic and Social Cohesion. A common policy to help less developed 
regions and member states meet the challenges associated with the single market began thereby to take shape, with the aim of ensuring economic and social cohesion. In the following year, 1988, the financial resources allocated to the Structural Funds were doubled.

The extension of Community powers for which the Single European Act provided, and the reform of European institutions to which it gave rise, also provided the basis for the economic and monetary union that would be established by the Treaty of Maastricht.

Parallel with negotiations on the Single European Act, moreover, Delors convened a meeting with the social partners: the European Trade Union Confederation (ETUC) and the Union of Industrial and Employers' Confederations of Europe (UNICE, now known as BusinessEurope). This was the start of the so-called Social Dialogue. A 'social Europe', Delors declared, was a precondition for further integration. In step with the opening up of various sectors of the European economy to competition (including the public sector), the social partners needed to discuss the conditions that would apply in the single market. The work that began with the Social Dialogue eventually led to the Community Charter of Fundamental Social Rights of Workers in 1989, and to the Social Protocol annexed to the Maastricht Treaty in 1992. The Amsterdam Treaty of 1997, finally, incorporated the Social Protocol directly.

The Union's social ambitions were further broadened in the year 2000, when it embraced the so-called Lisbon Strategy. The aim was to make Europe the most competitive economy in the world, while at the same time ensuring that growth is sustainable and social cohesion is not jeopardized. The method chosen for realizing these lofty ambitions - the Open Method of Coordination (OMC) - is based essentially on voluntary or 'soft' coordination, rather than on mandatory rules and legislation (Scharpf 2002). By comparing their different pension and social security schemes, for instance, member states would be able to learn from each other. The legal basis for social rights was also expanded, with the EU's adoption of the Charter of Fundamental Rights in 2001. The proposed treaty establishing a Constitution for Europe included the Charter, which was then adopted in modified form along with the Lisbon Treaty in 2009. The Lisbon Treaty also declared the Union's economic model to be that of a social market economy.

At the time of writing, in the wake of the economic crisis of recent years, the fight against poverty and social exclusion is once again said to be a top EU priority. Through the Europe 2020 strategy - the successor to the Lisbon Strategy - the EU aims to help at least 20 million people out of poverty and social exclusion (European Commission 2010). Furthermore, 75 per cent of the population aged 20-64 are to have a job by 2020 at the 
latest. The flagship initiatives of the Europe 2020 strategy, including the 'platform against poverty and social exclusion' and the 'agenda for new skills and jobs', are intended to help achieve these goals. Moreover, with the Commission's Social Investment Package, member states now receive advice on how to reform their welfare systems and to make social investments (European Commission 2013a). The European Semester, one of the most important reforms introduced after the crisis, furnishes the framework for supervising and monitoring the various economic and social reforms introduced by the member states for achieving the Europe 2020 objectives. The Commission proposes solutions to the different countries' problems in its country-specific recommendations.

Despite these efforts, the EU's social deficit has become more glaring. It is true that the Union, with its Europe 2020 strategy, has put the fight against poverty and social exclusion among the top items on its agenda. All the same, the development on the ground has been in the opposite direction. Economic disparities within the crisis-struck countries have gotten worse, as has the prosperity gap between the different member states. Let us therefore turn to the challenges ahead.

\section{THE CHALLENGES AHEAD}

According to the latest summary from the EU's own statistical agency, Eurostat (2016), around 120 million EU citizens suffer from poverty or social exclusion, or run the risk of falling into such a condition. This represents almost one in four EU citizens (24 per cent). And the differences between the member states are great. The situation is worst in Bulgaria, Romania, and Greece. By contrast, citizens of the Czech Republic, Finland, the Netherlands, and Sweden run a significantly lower risk of falling into poverty or social exclusion (Eurostat 2016). The Great Recession reversed a previous trend towards increased economic and social convergence among the member states. Prior to 2008, most social and employment indicators were moving in the same direction across the Union. Since 2008, by contrast, the trend has been towards a lasting polarization between the southern and peripheral member states on the one hand, and the northern and central member states on the other (European Commission 2013b).

But the prosperity gap within the EU is not just between countries; it is within them as well. Cross-national differences in levels of economic development covary with income inequalities within countries. In the states hardest hit by the economic crisis, unemployment became one of the key drivers behind growing income inequality (European Commission 2013b; EU SPC 2016). Approximately 21 million Europeans are currently out of 
work. But while unemployment in Greece and Spain is somewhere between one fourth and one fifth of the labour force, Germany and the Czech Republic have a rate of just 4 per cent (Eurostat 2016). Income inequality as measured by the quintile ratio - the ratio of the average income of the wealthiest 20 per cent of the population to that of the poorest 20 per cent increased significantly between 2008 and 2014 in the southern member states of Cyprus, Greece, Italy, and Spain, as in the similarly crisis-struck countries of Estonia, Hungary, and Ireland. With the notable exceptions of Germany, Luxemburg, Slovakia, Slovenia, and Sweden, countries that fared better during the financial crisis saw declining or stable rates of income inequality during those years (EU SPC 2016, p. 72).

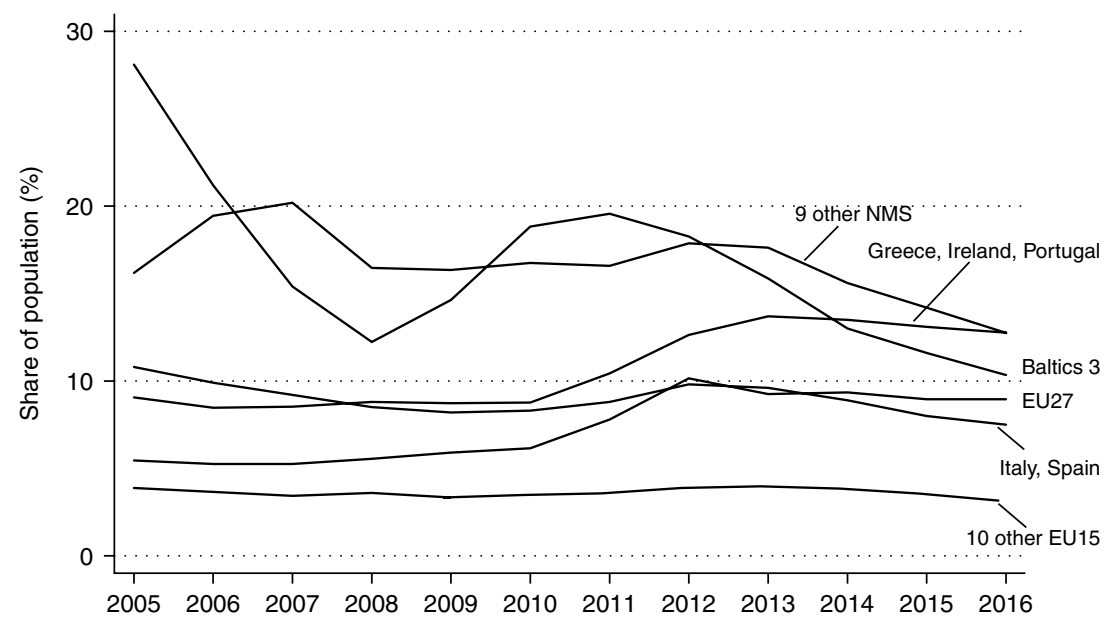

Note: Data for 2016 are estimates. The rate of severe material deprivation represents the proportion of people living in households that cannot afford at least four of the following nine items: (1) mortgage or rent payments, utility bills, hire purchase instalments, or other loan payments; (2) one week's holiday away from home; (3) a meal with meat, chicken, fish, or vegetarian equivalent every second day; (4) unexpected financial expenses; (5) a telephone (including mobile telephone); (6) a colour TV; (7) a washing machine; (8) a car; and (9) heating to keep the home adequately warm. The group ' 9 other NMS' includes all 'new' EU member states except the Baltic countries. Bulgaria was only included in this country group from 2006, Romania from 2007, and Croatia from 2010. The inclusion of Bulgaria and Romania explains the increasing rate of severe material deprivation in the group between 2005 and 2007. The group ' 10 other EU15' includes all 'old' EU member states except Greece, Ireland, Italy, Portugal, and Spain.

Source: Eurostat 2017, http://ec.europa.eu/eurostat/web/income-and-living-conditions. The country groupings follow those in Darvas and Wolff (2016).

Figure 1.1 The rate of severe material deprivation in six groups of EU member states, 2005-2016 
Looking at the most suitable indicator of poverty in the EU member states (the rate of severe material deprivation), a similar pattern of growing polarization can be observed. The rate of severe material deprivation represents the share of the population in each country that cannot afford things considered by most people to be necessary to live a viable life: to pay rent or utility bills; to keep one's home adequately warm; to eat meat, fish, or a protein equivalent regularly; and so on. As shown in Figure 1.1, Greece, Ireland, Portugal, and the three Baltic countries saw a sharp rise in the rate of severe material deprivation during the economic crisis. The Baltic states have returned to a rate comparable to that before the economic crisis, but the situation in Greece, Ireland, and Portugal continued to deteriorate until 2013, and since then it has only improved marginally. Thus, the rate of severe material deprivation in the EU spanned a wide range in 2016: averaging 3.2 per cent in the group of ten 'old' member states that fared better through the economic crisis, and 12.8 per cent both in the crisis-hit group made up of Greece, Ireland, and Portugal, and in the group of nine 'new' member states, excluding the Baltic countries.

A lasting prosperity gap, then, has established itself between Europe's wealthier countries and those which have lagged behind. As can be seen in Table 1.1, moreover, little overall progress has been made towards the employment and poverty targets set out in the Europe 2020 strategy. The employment rate in the Union as a whole was only slightly higher in 2016 than in 2008 (the baseline year for the 2020 targets), and the number of people at risk of falling into poverty has grown quite substantially.

In sum, the social challenge the EU now faces is colossal. The crisis has exposed the Union's inability to act effectively in the social field. Taxes and social welfare lie in all essentials beyond the ambit of Union decision making, as do most measures for the labour market. The social consequences of recent attempts to cope with the crisis - large-scale unemployment, widespread poverty, and increasingly threadbare social security systems - are thus left more or less to the member states themselves to deal with.

\section{ADDRESSING THE PROSPERITY GAP: AN INTERDISCIPLINARY APPROACH}

This book explores different ways of dealing with the social challenge facing Europe. Our point of departure is a broad and interdisciplinary understanding of what this challenge entails (for a similar approach to the EU's role in fighting global imbalances, see Bakardjieva Engelbrekt et al. 
Table 1.1 Progress towards the EU 2020 employment and poverty targets

\begin{tabular}{lccccc}
\hline & 2008 & 2014 & 2015 & 2016 & $\begin{array}{c}2020 \\
\text { Target }\end{array}$ \\
\hline $\begin{array}{c}\text { Employment rate } \\
\quad \% \text { of the population }\end{array}$ & 70.3 & 69.2 & 70.1 & 71.1 & 75.0 \\
$\begin{array}{c}\text { aged 20-64) } \\
\begin{array}{c}\text { People at risk of poverty } \\
\text { or social exclusion } \\
\text { (million people) }\end{array}\end{array}$ & 115.9 & 120.7 & 117.8 & 116.8 & 96.2 \\
\hline
\end{tabular}

Note: People at risk of poverty or social exclusion are (1) at risk of poverty after social transfers, or (2) severely materially deprived, or (3) living in a household with very low work intensity. Due to data availability, the poverty target is only evaluated for the EU27 and the figure for 2016 is an estimate. The employment target is evaluated for the EU28. Monitoring of the Europe 2020 indicators takes data from 2008 as a baseline year.

Source: Eurostat 2017, http://ec.europa.eu/eurostat/web/europe-2020-indicators.

2015). What economic, legal, and political measures are required to bridge the growing prosperity gap between the EU's member states?

From an economic perspective, it is essential to understand why crossnational differences in levels of economic development and prosperity increased so dramatically during the years of the Great Recession, along with income inequalities within some countries. It is also vital to analyse how public finances and national welfare systems are affected by market deregulation and the free movement of people within the Union. The EU has primarily sought to level out inequalities between its member states, by directing development aid and regional support to poorer areas. Indeed, the Union has been quite successful historically at reducing cross-national economic differences; but the Great Recession broke this trend (Beckfield 2009). An economic perspective is thus crucial for pointing out possible ways of bridging the prosperity gap in Europe.

From a legal perspective, it is important to understand the 'social acquis' of the EU. This involves 'hard law' measures such as EU primary law (the treaties), the EU Charter, social rights, principles of EU secondary law, and the case law of the European Court of Justice (ECJ). While the EU's main goal has been to promote economic and political integration, the ECJ has ruled on many cases involving social rights. It is of key importance to analyse the balance which it strikes between market rules and the social rights of EU citizens. In addition, moreover, to the EU's legally binding instruments, there are 'soft law' measures for coordinating the social and fiscal policies of the member states (European Commission 2016b). More 
recently, in an effort to ameliorate the social consequences of the Great Recession, the Commission has taken new initiatives in the area of social policy, including a European Pillar of Social Rights aimed at identifying a number of essential principles for all states in the eurozone in the field of employment and social policy (European Commission 2016a; 2017). The social pillar builds on and complements the 'social acquis' of the existing legal framework, and seeks to promote fair and well-functioning labour markets and welfare systems (European Commission 2016b).

The political perspective is crucial for understanding how governments and political actors can promote social cohesion in Europe, and how the challenge from populist parties sets limits on what can be done. The EU is currently struggling to cope with intensified conflict between winners and losers from market integration (Kriesi et al. 2006, 2012; Kriesi 2014). National welfare states are economically and legally constrained by European laws promoting economic integration, liberalization, and competition. At the same time, common social policies have proven hard to enact at the European level. When they have been enacted at that level, moreover, they have proven hard to carry out domestically, due to the diversity of national welfare systems. Not only do levels of economic development and prosperity vary among the member states (making for differing capacities to provide social transfers and services); there are also significant differences in terms of political aspirations to provide social welfare (Scharpf 2002).

Overall, European integration has led to an ever-increasing imbalance between market integration and social cohesion (Scharpf 2010). Economic, legal, and political mechanisms built into the EU system are fuelling a growing prosperity gap. Examining this gap from a range of disciplines, the authors in this book seek to deepen our understanding of its nature, and to propose measures whereby we can bridge it.

\section{OUTLINE OF THE BOOK}

The following nine chapters in this book seek to assess the EU's social challenge from the standpoints of economics, law, and political science. In Chapter 2 of the book, Anna-Sara Lind describes how the social rights which, according to the treaties, EU citizens possess - such as the right to social assistance, to health, and to work - find expression in a Union which is suffering not just from an economic crisis, but from a crisis of confidence as well. Lind argues that the confidence crisis itself puts limits on the prospects for realizing these rights, and undermines the solidarity between member states articulated in the Union's basic treaties. New 
wording in the Lisbon Treaty sought to consolidate the EU as a social market economy with clearly specified social rights, but this has not had the impact that might have been expected. As Lind's analysis in the chapter makes clear, the member states have taken a cautious line on the question of European social rights. Furthermore, the ECJ has found this to be a tricky and difficult area, and has hesitated to enter it. In this area of conflicting interpretations, political decisions have been transferred de facto to a judicial body.

It is therefore crucial, Lind contends, that the member states themselves take the next step now. Within a framework of mutual cooperation, they must actively interpret and utilize the basic rules which have a bearing on social rights. This way, the ECJ too may dare to break new ground - to interpret and apply the rules actively, and to take the step towards yet another paradigm shift in EU law. Lind underlines how essential it is for a well-functioning society and constitutional state that in challenging times it is possible to foresee - and to rely upon - the utmost provisions of the law. Perhaps - if the fundamental rights of citizens had been highlighted greater trust could have been generated for the measures taken to combat the economic crisis. Lind's overarching conclusion is that the policies for meeting the crisis could have been justified and explained in a new way, and also given a different content, if the fundamental rights of EU citizens had been taken into account. She stresses the importance of social rights for counteracting economic imbalances, both between member states and between citizens.

In Chapter 3, Ann-Cathrine Jungar asks whether Europe's right-wing populist parties pose a threat to freedom of movement and to the Union's fundamental values. Jungar's analysis shows that right-wing populist parties contribute to a better congruence of opinion between voters and parties in European party systems: as a result of their presence, the diverse preferences of voters on questions of immigration and the Union are reflected more fully. Jungar concludes from this that these parties have come into being and grown because there is a demand among certain groups of voters for their critical line on immigration and the EU. The classic political conflict between left and right on socio-economic issues continues to be the most relevant one for the majority of voters in Europe, but conflicts relating to socio-cultural issues - immigration and multiculturalism, equality between men and women, the position of sexual minorities, and so on - have gained greater relevance. This trend is closely connected to large-scale changes like globalization, European integration, and the growing denationalization of both economics and politics.

Jungar thus contends that right-wing populist parties put forward 
pertinent questions about the legitimacy of the EU, as well as about the limits of national, European, and global solidarity in the distribution of economic and social resources. Can this group of parties in some way provide a corrective, thereby helping to make European integration more relevant and credible for those European citizens who distrust it most? Jungar concludes, however, that these parties have little ability - notwithstanding their success in the last EP elections, in 2014 - to affect political decisions in the Union directly. Their indirect influence via national governments in the Council of Ministers has been strengthened, but their potential for exerting influence lies less in their own hands than in those of the other parties. The challenge for the established parties is to formulate answers, on the basis of their own ideologies and visions, to the questions that supporters of the right-wing populist parties ask. Among the central issues here, of course, is the degree of solidarity and redistribution to be effected between the EU member states.

In Chapter 4 of the book, Joakim Ruist looks at how the prosperity gap between the member states is affected by the EU's free movement of labour. The purpose of this free movement is to even out economic imbalances between countries in the Union. As these imbalances have increased over the last decade, however, freedom of movement within the Union has been questioned more and more. This reflects a fear that people from poorer parts of the Union will seek out the more generous welfare systems in the richer parts. Ruist argues, however, that both the hopes and the fears in this matter are exaggerated. In reality, differences in economic development lead only in small measure to labour migration among EU countries. Mobility in the Union is too low to make any significant contribution to economic equalization between the member states. A partial exception here is the movement of workers that has taken place from the new to the old member states since the EU's enlargement in 2004 and 2007. But contrary to what is often feared, migrants from the new member states have not entailed any net cost for welfare systems in the old member states. In fact Ruist shows that migrants contribute somewhat more to the public purse than they cost.

Ruist concludes that the Union and its member states should strive to uphold the free movement of labour, although it has never been challenged as much as it is today. He contends that the free movement of labour while less extensive than might be desired - has brought with it a number of positive effects. Although it does not bring about a high degree of economic equalization between EU states, it does indeed raise the living standards of hundreds of thousands of Europeans, namely those of the workers who move from lower-income to higher-income countries. Ruist demonstrates, furthermore, that the free movement of labour has no 
significant negative consequences for welfare systems anywhere. In view of this, he concludes, there is no persuasive reason to restrict it.

In Chapter 5, Pär Nyman analyses how the tension between fiscal discipline and responsiveness to popular demands contributes to widening the prosperity gap in Europe. On the one hand, he argues, the countries most affected by the Great Recession still have a pressing need to strengthen their budget balances and to reduce their debt levels. If they fail to improve fiscal discipline, they will remain vulnerable to economic crises in future. On the other hand, austerity is often met by public resistance, and the political consequences of going against voters' preferences can be dramatic. These consequences, Nyman finds, are not limited to the electoral performance of parties in power. A lack of responsiveness can also reduce trust in government more generally, and thereby pave the way for populist parties.

Nyman argues that if governments follow three policy recommendations, they should be able to reduce the tension they experience between fiscal responsibility and electoral responsiveness. First, he argues, they should build in larger safety margins during upturns in the business cycle, in order to minimize the risk for a future sovereign debt crisis. This can be achieved by introducing a debt-level target, as a complement to the debt ceiling in the Stability and Growth Pact, and by using backward-looking criteria when compliance with fiscal rules is evaluated. Second, Nyman argues, governments can lower the electoral costs of fiscal discipline by reducing the extent to which public expenditures increase with rising wages or prices. And when countries are caught in a situation where it is either economically or politically unsustainable to consolidate public finances, collective debt restructuring - whereby the creditor countries agree to write off a portion of the debt - may be the best option available. Third, to reduce the tension between responsibility and responsiveness further, measures must be taken to increase public support for fiscal discipline. Fiscal frameworks and fiscal councils should therefore be designed in such a way that they enhance fiscal transparency, increase the salience of the country's fiscal position, and contribute to the public debate on fiscal policy choices.

In Chapter 6, Lars Magnusson and Sofia Murhem review how the Social Dialogue between unions and employers at EU level has evolved over the past twenty years, and ask whether it has a role to play in the 2010s. Their analysis shows that the Social Dialogue, which had its breakthrough with the Amsterdam Treaty in 1999, has diminished in importance over time. The authors identify three factors here. First, the early success of the Social Dialogue was favoured by the involvement of a strong Commission with substantial legitimacy - something the Union lacks today. Second, 
the Social Dialogue has been weakened by the general decline of the social partners (the trade unions first and foremost). Third, the increase in the number of member states over the past decade has made it difficult to reach agreement; one reason for this is that a tradition of free and independent trade unions is lacking in the former communist states.

Magnusson and Murhem see several reasons to put a stop to this trend and to uphold a strong Social Dialogue in the EU. Over the long run, they contend, the Social Dialogue can strengthen the Union's legitimacy and increase citizens' support for it. Through central agreements between the social partners, the European labour market and European industry can develop in a way that benefits both sides. Furthermore, the authors stress, an active discussion is needed about increasing labour mobility among EU countries at a time of high unemployment in most countries, but of real mass unemployment in only a few. By means of a Social Dialogue, they claim, greater acceptance can be gained for increased labour mobility, and xenophobia can eventually be countered. They also highlight the ageing society, which puts pressure on the welfare and prosperity we have achieved in Europe, and the solution to which will require legitimacy in the form of a dialogue in which as many as possible feel like participants. The authors conclude that policy-makers at national and European level ought to promote the Social Dialogue, as an important tool for reducing the prosperity gap between the member states, enhancing the legitimacy of the EU as a whole, encouraging the mobility of labour, and combatting xenophobia.

In Chapter 7 of the book, Jenny Julén Votinius addresses the differences in prosperity and well-being that follow from the high levels of youth unemployment in the EU. Youth unemployment must be addressed when discussing the prosperity gap between EU countries, for the most deprived member states also have the worst youth unemployment. Equally important, however, is the prosperity gap which is rapidly opening up between different generations within the EU. When young people do not have access to the labour market on the same terms as their elders, clear differences in economic well-being arise. Julén Votinius reviews how youth unemployment has been handled in Europe during the crisis years, and discusses what can be done to reduce the prosperity gap which is being established between the generations. She examines the question with examples taken from labour law reforms that have been introduced recently in order to facilitate the entry of young people into the labour market particularly such reforms as those that involve weakening protections for young workers specifically.

The idea that hiring young people should be made more attractive by this means - by excluding them from a portion of the labour law protections 
available to others - is called into question in this chapter. The author rejects such an approach, citing among other things the concept of fundamental social rights - first and foremost the right to protection against age discrimination. She criticizes the compromise-oriented approach taken by the ECJ, which has stated that discrimination on grounds of age may be permissible if its purpose is to promote young people's employability. In the case of young workers too, Julén Votinius avers, respect for fundamental social rights must be seen as a key factor for meeting and reducing the prosperity gap between generations which is becoming established in the European labour market.

In Chapter 8, Jaan Paju analyses the future of national social insurance programmes in the EU. Social insurance is an important part of what makes up a welfare state, and it has been a state responsibility in Europe ever since the first law on workplace accident insurance was adopted in Prussia in the 1870s. In Europe in the year 2017, social insurance remains a national responsibility, but the EU's power to promote the internal market and to develop Union citizenship challenges the autonomy of the member states in such matters. Paju explains and analyses the tensions that arise in this area when different interests contend. The domestic social security systems of the member states are based on a form of solidarity which is nationally and territorially delimited, while the EU's system is based on a concept of economic integration through the free movement of persons and an increasingly significant and freestanding Union citizenship. Legal developments in this field raise the question of how the social security systems of the member states are to be organized in the future, in coordination with an expansive body of EU law.

Paju asks too whether coordination by the Union of national social security systems has a role to play in dealing with increased disparities among the member states, or whether such coordination serves in fact to counteract the EU's social dimension. He finds that the tug-of-war entailed by coordination in this area can only be constructive and sustainable over the long term if the current idea of the nation-state is revised, and migrants start to be seen as an opportunity to jointly promote the development of sustainable welfare systems within the Union. The starting point in this discussion should be what kind of Union the member states wish to see in 25 years, taking into account both current and future regional differences. The models to be developed for the future should aim to bridge the gap in social well-being which currently characterizes the EU, without eroding altogether the differences between the welfare models of the different member states. Paju underlines that, in an increasingly globalized world, the EU's future lies in community - not in national particularity.

In Chapter 9 of the book, Martin Ljunge examines how social trust gets 
conveyed across generations. Social trust, he points out, enhances health and prosperity. It is the confidence people feel for their fellow citizens in general - that is, for persons with whom they have no direct relation. By studying children of immigrants, Ljunge has managed to trace how social trust is conveyed within the family. He finds that children born to mothers from high-trust countries themselves show greater trust than do children born to mothers from low-trust countries. Children of mothers from hightrust countries also enjoy better health than do those whose mothers hail from low-trust ones. This second correlation shows that greater trust leads to better health. The direction of causality is clear: it is trust that leads to better health, and not vice versa; the child's health, namely, cannot influence the average trust in the mother's home country, inasmuch as the child was born and lives in another country.

Ljunge shows too that high trust has a number of other positive effects. For example, children whose mothers come from high-trust countries have higher incomes than do those whose mothers come from low-trust ones. Those who show high levels of trust also spend more time working than do those who show low levels, and less time unemployed or in retirement. The results indicate that trust is a factor behind persistent differences in health and wealth between individuals - and between countries as well. There are large differences in this regard, namely, between northern, southern, and eastern Europe. Here, the author argues, the EU and its member states have an important role to play. They can work actively to increase trust among citizens, and thus to reduce the long-term prosperity gap within and between EU countries. The most important measure that member states could take, according to Ljunge, would be to institute programmes for inculcating social skills in young people at risk. Experience from a programme focused on boys at risk during their first years of school has been very promising. This is an example of a measure that can dramatically increase young people's chances of educating themselves, to establish themselves in the labour market, and to develop working relationships.

In the final chapter of the book, Chapter 10, Nicholas Charron and Bo Rothstein explore the factors that operate at a societal level to build or destroy social trust. Their analysis in this chapter is based on the unique data available about the quality of public institutions at the regional level within the EU. This data, collected in 2010 and 2013 at the Quality of Government Institute in Gothenburg, enables researchers to compare the quality of public institutions both within and between countries. It includes 206 regions in 25 countries in Europe, and its standardized questionnaire was answered by 85,000 respondents in 2013. Using this extensive material, Charron and Rothstein test the tenability of four common explanations for variations in social trust among groups, countries, and regions: economic 
inequality, ethnic diversity, the quality of public institutions, and the degree of political participation by citizens.

The authors find sharp variations in social trust within many countries, a phenomenon overlooked in previous studies (based as they were on country-level data). They also find strong evidence to the effect that the quality of public institutions - measured as the degree to which a non-corrupt public sector delivers services in an impartial way - is the strongest factor underlying regional variations in trust within countries. Economic inequality as well proves to be a factor to be reckoned with for explaining variations in social trust. By contrast, the degree of ethnic diversity and the extent to which citizens participate politically have less importance for variations in trust. Charron and Rothstein's results are clearly relevant for the choices the Union and its member states face both in their work of building and reforming their own public institutions and in their encounter with the larger world. The overall conclusion of the chapter is that increasing the quality of public institutions should have first priority if our aim is to reduce the prosperity gap between countries and regions in Europe. Charron and Rothstein also highlight the possibility, as a promising hypothesis for future research, that high-quality public institutions serve to strengthen the capacity of countries to welcome immigrants, since good governance can also be expected to increase trust between those who already live in a country and those who have recently arrived in it.

The chapters in this book seek to assess the EU's social challenge from the standpoints of economics, law, and political science. An important conclusion from the chapters is that the Union's future role for Europeans depends on its ability to counteract the prosperity gap that has emerged during the crisis. If the Union is to reach the ambitious goals set out in the Europe 2020 strategy, far-reaching measures will be needed. At the same time, the idea of a social Europe faces major opposition from political forces that seek to roll back European integration, to reduce freedom of movement within the Union, and to close the borders to newcomers.

Much will therefore be at stake in the coming months, as the EU formulates its social policy for the years to come. The new initiative to boost growth and jobs recently launched by the Commission includes substantial social investment. In a speech to the EP in Strasbourg, Commission President Jean-Claude Juncker declared: 'Investing in Europe: It means much more than figures and projects, money and rules. We need to send a message to the people of Europe and to the rest of the world: Europe is 
back in business. This is not the moment to look back. Investment is about the future.'

The question, however, is whether the Commission's growth initiative really stakes out a new path for the EU, or whether instead it reflects the past. The social market economy the Union claims to represent is built in all essentials on the member states' own efforts in the social welfare area, while the market on the other hand is common. The EU's contribution is to support economic growth in the weaker regions, thereby promoting social cohesion. Thus it has been since the European Social Fund was created by the Treaty of Rome. But the dream of a social Europe - in the sense of an ambitious social policy pursued at the European level - remains a dream. Some hope that the dream will come true; others prefer that it remains a dream.

\section{REFERENCES}

Arnorsson, Agust and Gylfi Zoega (2016), 'On the Causes of Brexit', CESifo Working Paper Series No. 6056, accessed 22 November 2016 at https://ssrn.com/ abstract $=2851396$.

Bakardjieva Engelbrekt, Antonina, Moa Mårtensson, Lars Oxelheim and Thomas Persson (2015), The EU's Role in Fighting Global Imbalances, Cheltenham, UK and Northampton, MA: Edward Elgar Publishing.

Beckfield, Jason (2009), 'Remapping Inequality in Europe: The Net Effect of Regional Integration on Total Income Inequality in the European Union', International Journal of Comparative Sociology, 50:5-6, 486-509.

Castillo Ortiz, Pablo José (2017), 'The Political De-determination of Legal Rules and the Contested Meaning of the "No Bailout" Clause', Social and Legal Studies, 26:2, 249-272.

Committee for the Study of Economic and Monetary Union (1989), Report on Economic and Monetary Union in the European Community, Brussels, April 1989, accessed 26 November 2016 at http://ec.europa.eu/economy_finance/ publications/publication6161_en.pdf.

Darvas, Zsolt and Guntram B. Wolff (2016), 'An Anatomy of Inclusive Growth in Europe', Bruegel Blueprint 26, accessed 2 November 2017 at http://bruegel. org/2016/10/an-anatomy-of-inclusivegrowth-in-europe/.

EU SPC (2016), Social Protection Committee Annual Report 2016. Review of the Social Protection Performance Monitor and Developments in Social Protection Policies, Brussels, October 2016.

European Commission (2010), 'Europe 2020: A Strategy for Smart, Sustainable and Inclusive Growth', COM(2010) 2020 final, Brussels, March 2010.

European Commission (2013a), 'Towards Social Investment for Growth and Cohesion - Including Implementing the European Social Fund 2014-2020', $\operatorname{COM(2013)} 83$ final, Brussels, February 2013.

European Commission (2013b), Employment and Social Developments in Europe 2013, Brussels, January 2014. 
European Commission (2014a), 'Time for Action - Statement in the European Parliament Plenary Session Ahead of the Vote on the College', European Commission - Speech, Brussels, October 2014.

European Commission (2014b), 'An Investment Plan for Europe', COM(2014) 903 final, Brussels, November 2014.

European Commission (2016a), 'Launching a Consultation on a European Pillar of Social Rights', COM(2016) 0127 final, Brussels, March 2016.

European Commission (2016b), 'The EU Social Acquis', SWD(2016) 50 final, Brussels, March 2016.

European Commission (2017), 'Establishing a European Pillar of Social Rights', $\operatorname{COM}(2017) 250$ final, Brussels, April 2017.

Eurostat (2016), Europe 2020 Indicators - Poverty and Social Exclusion, Brussels, October 2016.

Fernandes, Sofia and David Rinaldi (2016), 'Is There Such a Thing as "Social Europe'?', Tribune, Jacques Delors Institute, September 2016.

Ferrera, Maurizio (2005), The Boundaries of Welfare: The New Spatial Politics of Social Protection, Oxford: Oxford University Press.

Ferrera, Maurizio (2014), 'Social Europe and Its Components in the Midst of the Crisis: A Conclusion', West European Politics, 37:4, 825-843.

Greenhill, Kelly M. (2016), 'Open Arms behind Barred Doors: Fear, Hypocrisy and Policy Schizophrenia in the European Migration Crisis', European Law Journal, 22:3, 317-332.

Gustavsson, Sverker (1998), 'Double Asymmetry as Normative Challenge', in Andreas Follesdal and Peter Koslowski (eds), Democracy and the European Union, Berlin and Heidelberg: Springer, pp. 108-131.

Gustavsson, Sverker (2002), 'What Makes a European Monetary Union without a Parallel Fiscal Union Politically Sustainable?', in Søren Dosenrode (ed.), Political Aspects of the Economic and Monetary Union: The European Challenge, Aldershot, UK: Ashgate, pp. 87-118.

Inglehart, Ronald and Pippa Norris (2016), 'Trump, Brexit, and the Rise of Populism: Economic Have-Nots and Cultural Backlash', HKS Working Paper No. RWP16-026, accessed 22 November 2016 at https://ssrn.com/abstract=2818659.

Jabko, Nicolas (2006), Playing the Market: A Political Strategy for Uniting Europe, 1985-2005, Ithaca, NY: Cornell University Press.

Keeley, Brian (2015), Income Inequality: The Gap between Rich and Poor, OECD Insights, Paris: OECD Publishing.

Kriesi, Hanspeter (2014), 'The Populist Challenge', West European Politics, 37:2, 361-378.

Kriesi, Hanspeter, Edgar Grande, Martin Dolezal, Marc Helbling, Swen Hutter, Dominic Höglinger, and Bruno Wüest (2012), Political Conflict in Western Europe, Cambridge: Cambridge University Press.

Kriesi, Hanspeter, Edgar Grande, Romain Lachat, Martin Dolezal, Simon Bornschier, and Tim Frey (2006), 'Globalization and the Transformation of the National Political Space: Six European Countries Compared', European Journal of Political Research, 45:6, 921-956.

Majone, Giandomeinico (1993), 'The European Community between Social Policy and Social Regulation', Journal of Common Market Studies, 31:2, 153-170.

Martinsen, Dorte Sindbjerg, and Hans Vollaard (2014), 'Implementing Social Europe in Times of Crises: Re-established Boundaries of Welfare?', West European Politics, 37:4, 677-692. 
Portes, Jonathan (2016), 'Immigration, Free Movement and the EU Referendum', National Institute Economic Review, 236:1, 14-22.

Raitano, Michele (2016), 'Income Inequality in Europe since the Crisis', Intereconomics, 51:2, 67-72.

Scharpf, Fritz W. (2002), 'The European Social Model', Journal of Common Market Studies, 40:4, 645-670.

Scharpf, Fritz W. (2010), 'The Asymmetry of European Integration, or Why the EU Cannot Be a "Social Market Economy", Socio-Economic Review, 8, 211-250.

Scharpf, Fritz W. (2012), 'Monetary Union, Fiscal Crisis and the Pre-emption of Democracy', Zeitschrift für Staats- und Europawissenschaften, 9:2, 163-198.

Streeck, Wolfgang (2016), 'Exploding Europe: Germany, the Refugees and the British Vote to Leave', SPERI Paper No. 31, Sheffield: Sheffield Political Economy Research Institute.

Thielemann, Eiko and Daniel Schade (2016), 'Buying into Myths: Free Movement of People and Immigration', Political Quarterly, 87:2, 139-147. 